\title{
HOUSE PRICE CHANGES AND ISLAMIC BANK STABILITY: EVIDENCE FROM MALAYSIA
}

\author{
Shiau Hui Kok ${ }^{1}$ and Normaz Wana Ismail ${ }^{2}$ \\ ${ }^{1}$ Sunway College, Malaysia, shkok@sunway.edu.my \\ ${ }^{2}$ Universiti Putra Malaysia, Malaysia, nwi@upm.edu.my
}

\begin{abstract}
In this paper, we examine the relationship between house price and Islamic bank stability in Malaysia. In particular, in relating to Islamic bank stability to Malaysian house price changes, we evaluate the nature of the relationship from the perspective of nonlinearities. The Autoregressive Distributed Lag (ARDL) model is applied to a sample that consists of 9 Islamic banks in Malaysia for the period of 2000-2016. Our results indicate that there is an inverted U-shaped relationship between house price and Islamic bank stability in the long run. Meanwhile, the relationship is insignificant in the short-run. To put it differently, initially, the higher house prices, the more stable the bank. Then, the impact of house prices on bank stability becomes negative when house prices surpass the threshold point. As far as the bank-specific characteristics are concerned, the cost to income ratio is found to significantly and negatively related to the bank stability. Such a result has policy implications in which it is crucial for achieving balance in the housing market, and efficiently managing the cost is equally important to ensure Islamic bank soundness.
\end{abstract}

Keywords: House Prices, Islamic Bank Stability, ARDL, Non-Linear, Malaysia. JEL Classification: C22; G21; O11; R30.

\author{
Article history: \\ Received : October 03, 2018 \\ Revised : February 17, 2019 \\ Accepted : February 26, 2019 \\ Available online : March 15, 2019
}

https://doi.org/10.21098/jimf.v5i1.1044 


\section{INTRODUCTION}

The rapid appreciation of house prices subsequently followed by the financial crisis tends to suggest that house price changes as an essential indicator predicting future financial distress. Such a notion gives prominence to the overvaluation of the housing market and the soundness of the bank. Meanwhile, there is an increasing attention on the financial stability of Islamic banking in the recent year. Empirical evidence shows that the financial crisis has affected Islamic banks differently compared to conventional banks. Islamic banks seem to perform better with a more favorable credit risk during the financial crisis (Hasan \& Dridi, 2010). Beck et al. (2013) suggests that Islamic banks have a better asset quality management and higher capitalization, and are more stable than conventional banks. Baele et al. (2014) argues that Islamic banks have lower probability of default as they have lesser default loan.

Despite the strong evidence which Islamic banks are more stable than conventional banks, they not without failure. For example, the Souk al-Manakh crisis caused a crash in the stock market in 1982. The crash quickly propagated to the real estate sector, and most of Kuwait's banks become insolvent. Islamic Bank of South Africa failed in 1997 due to its poor credit risk management, insecure lending, and fraud. Ihlas Finans House collapsed during the banking crisis in 2000. By law, the Islamic bank could not invest in securities. When the shock kicked in, Ihlas Finans House faced a run as most of the investments were in illiquid asset (Ahmed et al., 2014).

Islamic finance has grown exponentially in the past three decades. The global Islamic banking asset achieved \$1.9 trillion in 2015 (World Bank, 2016). Presently, Malaysia Islamic banking asset hits approximately $\$ 150$ billion and stands $27 \%$ of Malaysia's total banking system (The Malay Mail, 2016). On the one hand, Islamic banking captures $23 \%$ of market share in the entire Malaysia banking sector. From 2006 to 2016, the average y-o-y growth Islamic bank lending has managed a double-digit growth of nearly $20 \%$. Whereby, the total lending for the purchase of residential property expands tremendously, from RM17.1 billion in 2006Q4 to RM108.5 billion 2016Q3. The total lending for the purchase of residential property became the largest proportion since 2014 (BNM, 2016).

Unlike the conventional bank, Islamic banking adheres to the Islamic law, such as profit and risk sharing, the prohibition of interest, and the prohibition of holding a toxic asset. Meanwhile, Islamic banking still confronts extra risk due to its complexity mode and limited investment choices. In Malaysia, there is a notable high proportion of Islamic bank lending to the property sector. Financing to the activity of the property sector has been the focus as such a financing fits the Islamic principle, which involves asset-based in all transaction. In other words, real estate exposure may be the most significant threat to Islamic banking, especially as the majority of the balance sheet binds to the real estate asset.

Theoretically, the relationship between house price and the bank can be explained by the deviation hypothesis and collateral hypothesis. The positive correlation between house prices and bank stability refers to the deviation hypothesis. According to this viewpoint, persistently high house prices could increase the accumulation of risky assets and larger bank exposure when banks lend to the risky borrower given that everyone is expecting the price to continue 
to grow. Meanwhile, the collateral hypothesis suggests that higher house prices improve bank stability given the collateral value have increased. In the past two decades, Malaysia house price grew steadily, nearly $3.2 \%$ annually. Then, the house price recorded a remarkable high growth rate, exceeding $9 \%$ annually after 2010. According to the Central Bank of Malaysia or Bank Negara Malaysia (BNM), the Malaysia house price grew steadily, approximately $3.2 \%$ in the past decades.

Figure 1.

The Average Z-Score Index For The Islamic Bank From 2000Q1 To 2016Q3.

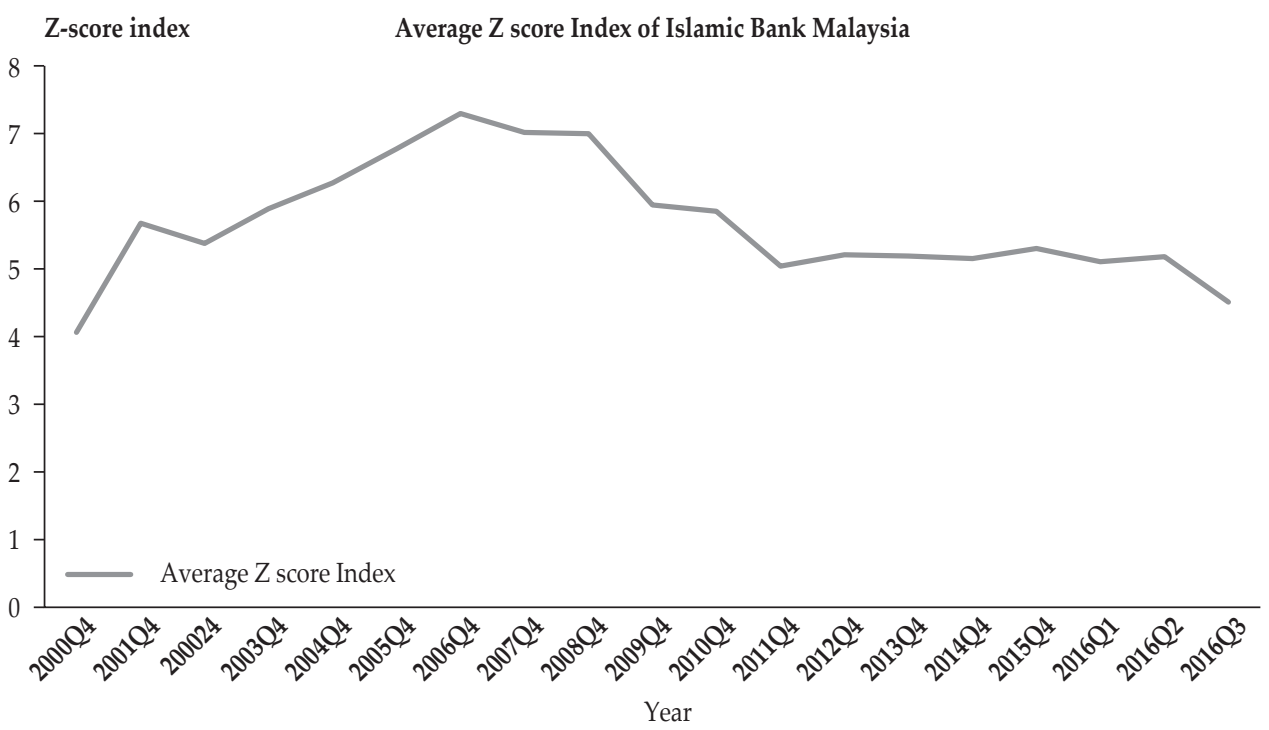

Sources: Individual Bank's Annual Report. (Author's own calculation)

One of the reasons attributed to the rapid expansion in housing price after the year 2010, was the increase in speculative purchases in 2010 (BNM, 2015). As a large proportion of credit has been lending out to the property market, the unsustainable boom in the real estate market may adversely affect the Islamic bank and the economy. Additionally, the property foreclosure rate in Malaysia shows an upward trend in recent year. Approximate 2,056 properties are being put up for auction every month (The Edge, 2016). As the home foreclosure rate is on the rise, this signifies uncertainty in the housing market and may jeopardize the bank. Generally, the Z-score index is the common measures of bank stability. The analysis of index involves the collection and interpretation of the accounting data, which allow us to evaluate how the individual bank's capital can absorb the variability of returns. Based on the historical trend analysis (refer figure 1), before the housing boom, the Islamic Bank's Z-score exhibit a generally upward trend. The Z-score value is lingering at a value between 5 to 7 -unit point. Then the series showed evidence of a decrease after the year 2010. When the house price is accelerating, the risk taker investor could have seeking fund from the bank and expecting a further price increase. This could have accumulated some amount of risky asset for the bank. Another possible reason to explain the plunge of Z-score 
index is the increase in the number of full-fledged Islamic banks. By the year 2010, the number of Islamic Bank increased to seventeen as banking licenses were issued to foreign Islamic banking players. This translated to greater competition among the Islamic banks. These banks may hold lesser capital and lending out more loans under a more competitive environment, leading to a drop in Z-score (Keeley, 1990; Beck et al., 2013; Jiménez et al., 2013).

In light of these, the present paper contributes to the existing literature by empirically examining the relationship between house prices and Islamic bank stability in Malaysia. We explore the nature of this relationship from the nonlinear perspective. Some studies suggest an asymmetric relationship between banks and asset prices (Pan \& Wang, 2013; Gennaioli et al., 2012; Dieci \& Westerhoff, 2012). For instance, the theory of "local thinking" underpins the nonlinear relationship between the asset price and bank stability. These studies argue that investors are subject to limited ability and rely on a simple heuristic in predicting the return. The "local thinking," which was introduced by Gennaioli \& Shleifer (2010), explained that not all the contingencies are included in the decision-making. As such, financial fragility may arise when new securities are issued excessively. A significant decline in asset price causes adverse effects after a market shock. On the other hand, when speculative force mingles with the housing demand and supply, this creates a complex price dynamic. Some optimistic investors expect continuous growth in housing, but some believe the mean reversion theory, which leads to the asymmetric response to the information (Dieci \& Westerhoff, 2012).

Our study seeks to contribute to the literature as follows. First, we adopted the autoregressive distributed lag (ARDL) approach to estimate the long run and short-run relationships between changes in house prices and Islamic bank stability in Malaysia. Although ample studies have evaluated the impact of house prices and bank stability, the focus is on the conventional banks from advanced economies. Second, we use a Z-score to measure bank stability. We used the disaggregate bank-specific data in computing the Z-score to measure the solvency risk at the level of the individual institution. Finally, we address the presence of nonlinearities in estimating the relationship between house prices and Islamic bank stability. This allows us to examine whether Z-score responds differently to changes in house prices when house prices reach a certain extreme point.

In summary, this paper reveals supported evidence of the house price changes affects Islamic bank stability. According to Khor and Kee (2008), persistent house price acceleration distorted the equilibrium in the market. Aforementioned, Malaysian Islamic banks are potentially exposed to the real estate market. In the past decades, the ratio of house financing to the total lending in the Islamic banking system grew from $17.6 \%$ to $28.4 \%$ (BNM, 2018). Whereby, the housing market in Malaysia posted slowing down in the recent year. This could be a major threat for the bank especially the number of unsold residential properties showing an upward trend. Hence, further analysis of the house price changes and financial soundness is essential. The remainder of this paper is structured as follows: section 2 presents a review of past studies; section 3 describes the data source and methodology applied in this research study; section 4 presents the discussion of result; and section 5 will be the concluding remark. 


\section{LITERATURE REVIEW}

\subsection{Theoretical Literature}

According to the classic banking theory, the linkage between the housing market and finance structure has been addressed in the model of Bernanke and Gertler (1989) and Kiyotaki \& Moore (1997). Bernanke and Gertler (1989) underline the asymmetric information in explaining the interaction between the asset price, bank and economy. During the economic downturn, the presence of asymmetric information increases the agency cost and jeopardizes the borrowing. This causes the collateral value to plunge and further amplified the impact of output volatility. On the other hand, Kiyotaki and Moore (1997) emphasized the interaction between the asset price and credit constraint and has explained that a slight economic shock might be intensified due to the existence of credit constraint. The model assumed that collateral is required for every lending to occur, and this has caused a more fluctuating output. Thus, the housing market boom is associated with the expansion of the bank's balance sheet as the capital value has increased. Consequently, this has enabled the bank to borrow more, given that the net worth has gained.

The second strand of the theories highlighted the bank's fundamental financial structure in explaining financial instability. Chiesa (2001) and Diamond and Rajan (2006) suggested that the bank is vulnerable when the borrowers fail to fulfill the obligations. Bank further tightened the bank lending in response to the bank losses and triggered the depositor run. This exacerbated the effect of financial distress. However, Chiesa (2001) particular emphasizes that the credit derivation determines by the profit margin given to the monitoring cost. Hence, the capital requirement is essential to suppress the risk-taking incentive. Meanwhile, Von Peter (2009) extended the model by Diamond and Rajan (2006) and demonstrated a framework to show the linkage between bank loss, bank default and real estate. He recognizes the difference between macroeconomic and financial instability, while macroeconomic and financial instability could reinforce each other. He argues that bank financial position deteriorated when house prices decline and weaken the bank asset. Then, the bank could be unstable even without a bank run.

The capital crunch model, which introduced by Holmstrom and Tirole (1997), formulated a moral hazard framework to describe the relationship between bank's capital and firm's net worth, while Chen (2001) extended the model by including the asset price as the key variable. More specifically, these models differ from the existing literature by taking into consideration of the spillover effect to the bank when the firm's balance sheet deteriorated. Following the shock, the bank fragility magnified the impact and affected the investment.

As credit risk is the primary concern for the bank, some studies develop a model to show the interaction between housing market, credit risk and financial stability. This can be elaborated by the collateral value hypothesis suggesting that higher asset price increases collateral value and reduces the credit risk. The model proposed by Daglish (2009) acknowledges the collateral value effect and focus on the probability of default by observing the borrower's optimal default decision. He has argued that the likelihood of default is highly responsive to the variation of interest rate and house price, and default rate tends to be high during a surge of interest rate and fall of housing price. However, moral hazard arises in banking 
when there are changes in collateral value. This is further discussed by Niinimaki (2009). The study has proposed that banks should finance those risky projects as they expect an appreciation of the asset with a significant profit in the future. Additionally, the banks are exposed to risks when bank assets depreciate. On the other hand, the deviation hypothesis posits a positive relationship between house price and the credit risk. When the asset price is too high and substantially greater than its fundamental value, the bank risk is significantly higher. The bank crisis model presented by Allen \& Gale (2001) demonstrates that excessive expansion of credit advocates speculative activities. As a result, the asset price increases and surpasses its fundamental value. When the asset return is uncertain, the bank is at risk.

\subsection{Empirical Literature}

Our empirical literature mainly emphasizes on the relationship between house price and bank stability. In the literature, there are several measures of bank stability. Many studies agree that non-performing loans have been a crucial indicator to show the resilience of the financial system, for instance, Reinhart and Rogoff (2008), Messai and Jouini (2013), Vogiazas \& Nikolaidou (2011). These studies concluded that bank provisions increase with non-performing loans and strike at the bank capital, and as the sources of systemic risk. Some other studies applied bank's specific factors (CAMEL) as a measure of bank stability, the reviews are included Bongini et al. (2001), Calomiris \& Mason (2003b), and Cebula et al. (2011). However, the drawback of using this measure is the CAMEL rating is not forward-looking and may not be good enough to track the emerging risk. Another balance sheet variable such as Z-score ratio is described as the alternate proxy of bank stability (Boyd \& De Nicolo, 2005; Khaddafi et al. 2017; De Young \& Torna, 2013). Z-score measures the distance to default and is used in the banking system. They have calculated the standard deviation of the return of asset, return of equity, the ratio of loan loss provision and insolvency risk to represent the bank risk.

Some studies make a comparative analysis of bank stability between the Islamic bank and the conventional when the shock hits the bank. For instance, Alqathani and Mayes (2018) focus on the bank from Gulf Cooperation Council and argue that Islamic bank is more vulnerable compared to the conventional bank if Islamic banks operate at a large scale, especially in the later stage of the crisis. This empirical estimation seems to support the findings of Cihak and Hesse (2010) and Abedifar et al. (2013). Although the Islamic bank is practicing the risk sharing, the significant exposure to the real estate market has resulted in instability. In contrast, Bourkhis and Nabi (2013) reveal no significant difference in stability for both conventional and Islamic banks during the financial panic.

Majority of the studies explore the impact of house price on bank stability through the credit risk channels. The relationship between housing and bank stability has been highlighted in the study of Koetter and Poghosyan (2010), Pan and Wang (2013). Koetter and Poghosyan (2010) evaluate the real estate prices and bank stability by accessing the probability of bank distress due to the rapid growth in the German real estate market. They addressed that the deviations of house prices from their fundamental value are one of the potential risks that 
contribute to the instability of financial systems. They showed evidence to support the deviation hypothesis. In other words, house prices in Germany exceeded their fundamental value and harmed the banking stability. Alternatively, Pan and Wang (2013) examined the impact of house price changes on bank stability at various income levels in 286 of U.S. housing markets. They showed evidence of a negative link between housing markets and bank stability. Nevertheless, the house price deviation increased nonperforming loans during the economic downturn.

The relationship between real estate and the Islamic bank has been described in the study of Abdul-rahman et al. (2017), Abdul-Rahman (2009) and Chakroun \& Gallali (2011). Abdul-rahman et al. (2017) explore the relationship between financing structure and bank liquidity in Malaysia. They compare the impact of real estate financing on conventional and Islamic banks. They concluded that real estate finance increased the liquidity risk of Islamic banks, but had no impact on the conventional bank. These findings fit with the work of Abdul-Rahman (2009), who found Malaysian Islamic banking highly exposed to real estate financing. It was demonstrated that Islamic banking is in favor of offering lending and credit to real estate even though it is riskier. Meanwhile, Chakroun \& Gallali (2011) argue that the subprime mortgage crisis has a negative impact on the conventional bank but no impact on Islamic bank. However, Islamic banks have a lower recovery rate of the non-performing loan.

Ibrahim and Rizvi (2017) assess Islamic bank stability in Malaysia. They considered the size of the bank in explaining bank stability. The larger bank is found to be more stable in the study, especially when the bank is subjected to the capital stringency. While Wasiuzzaman and Tarmizi (2010) also focus on the Malaysian Islamic bank. They explore the relationship between asset quality and bank profitability and confirm a negative relationship. This result seems to contradict the studies done by Kosmidau et al. (2005) and Choong et al. (2012). They evaluate the impact of three risks, namely liquidity risk, concentration risk and credit risk on the profitability of an Islamic bank, and concluded a positive relationship.

Besides that, the relationship between bank-specific variables and stability has been highlighted in the studies of Zarrouk (2012) and Berger \& Deyoung (1997). Zarrouk (2012) argue that bank-specific variables are adversely affected the bank performance especially after the financial crisis of 2008. Islamic banks also found to involve in excessive risk-taking in UAE. Meanwhile, Berger \& Deyoung (1997) found evidence to support the bad management hypothesis and the moral hazard hypothesis. They conjecture that cost efficiency and capitalization are important variables in determining bank risk. A similar result is concluded by Podpiera \& Weill (2008). They focused on the emerging market, and suggest cost inefficiency raised nonperforming loans. Despite this evidence, Salas \& Saurina (2002) study the case of Spain in favor of the moral hazard hypothesis. They showed evidence that the high capitalization enhanced the quality of the loans. This implies that banks tend to offer risky loans when the capital is low.

On aggregate, based on our theoretical and empirical review, a vast body of studies documented evidence that bank profitability, loan loss, cost efficiency and liquidity are the major drivers of bank instability. However, the impact of house price changes on bank stability is non-negligible. Despite that, there is no 
conclusive answer to the question of whether the higher house price is positively or negatively related to financial stability. Additionally, the majority of the studies employed cross-country data, and consequently made the comparability between the key variables more complex. Given the mixed findings, our research aims to reconcile the contradiction by testing both collateral and deviation hypothesis.

\section{METHODOLOGY}

\subsection{Data}

The data are quarterly data, the period of analysis span from 2000Q1 to 2016Q3. The coverage period is based on data availability. The quarterly data on the house price index was obtained from the National Property Information Centre (NAPIC), and the data for the unemployment rate were extracted from the data stream. One reason that the unemployment rate is included as the proxy for economic conditions is the unemployment rate could have triggered the loan default and affected the new loan demand. This could further depress the bank's Z-score. On one hand, we consider the effect of bank characteristic on bank stability. These are included capitalization (equity/total asset), management skill (cost to income ratio), and earnings (return to asset). The higher capitalization is expected to promote bank stability. This is because greater capital enables risk absorption. While the interaction between the cost and income ratio is expected to yield a negative sign. The lower cost to income ratio implicates more cost efficiency and thereby more stability. Meanwhile, a positive sign is possible if the non-finance income did not drive the lower cost efficiency ratio. Besides that, higher profitability is expected to enhance bank stability. Following the study by Pan \& Wang (2013) and Koetter \& Poghosyan (2010), we measure the bank stability using Z-score. The Z-score is calculated as the sum of return on assets and equity to total asset ratio, and its relation to the standard deviation of return on assets of a bank. The data are collected from the published annual financial statement of 9 local Islamic banks ${ }^{1}$. The financial report of the respective bank is made available in Central Bank Malaysia. The list of the banks are presented in Appendix A. Additionally, to mimic the house price data, the bank-specific data and the Z-score are aggregated by using the simple average approach. On the other hand, all variables are seasonally adjusted following the census X-12 procedure. This approach is based on the moving averages, and smooth out the series by eliminating the regular seasonal fluctuation.

1. There are total 10 local Islamic Bank in Malaysia. To address the issue of an outlier, our study has excluded Bank Islam Malaysia Berhad. Bank Islam Malaysia has suffered a massive loss in the year 2005 and therefore the financial ratio has been underperformed relative to all other Islamic banks. As only 18 observations (18 years) obtained from the annual report, we carry out a frequency conversion by using Eviews. The linear match last approach is selected. To tackle the measurement bias, following the study by $\mathrm{Li}$ (2015) a sensitivity test on the interpolated series is done. 


\subsection{Method}

In this section, we briefly explain the model specification and method applied in this study. Following the study by Segoviano and Goodhart (2009) and Pan \& Wang (2013), our baseline model as follow:

$$
\begin{aligned}
& \text { stability }=f \text { (macroeconomic factor, bank-specific variable, house price) } \\
& Z I S L_{t}=\alpha+\beta_{1} U N_{t}+\beta_{2} X_{t}+\beta_{3} H P I_{t}+\varepsilon_{t}
\end{aligned}
$$

To restate, the Z-score is used to measure bank stability. ZISL denotes the z-score for Islamic bank. House price index is the proxy of the house price. In addition to that, macroeconomic changes often related to bank stability. As the unemployment rate has a direct impact on loan loss, we include the unemployment rate as one of the key variables. At the bank level, we employ three control bankspecific variables that denote $X$ in equation 2 which include cost efficiency ratio (COST).

As the relationship between house price changes and bank stability is potentially nonlinear. One of the fundamental reason to explain the nature of the relationship is the bounded rationality decision making. Hence, our study included the squared term of HPI in the model. The model (2) is extended, and the model is outlined in the following manner:

$$
Z I S L_{t}=\alpha+\beta_{1} U N_{t}+\beta_{2} X_{t}+\beta_{3} H P I_{t}+\beta_{4} H P I_{t}^{2}+\varepsilon_{t}
$$

To detect the long-run relationship between bank stability and house prices, we use the ARDL approach (Pesaran and Shin, 1999). All to all, the estimation involves taking four steps. First, the stationarity of the variables will be tested. This is because integration of $\mathrm{I}(2)$ is not permitted. In addition to that, the structural break unit-root test is performed to detect the potential structural break of the series. This is followed by the model estimation using the standard OLS method. Then, the general to the specific procedure will be carried out to reduce the inclusion of insignificant lag. The ARDL approach is applied to the model 3 and can be expressed as follow:

$$
\begin{aligned}
\Delta Z-\text { score }_{t}= & \alpha_{0}+\alpha_{1} Z-\text { score }_{t-1}+\alpha_{2} U N_{t-1}+\alpha_{3} X_{t-1}+\alpha_{4} H P I_{t-1}+\alpha_{5} H P I_{t-1}^{2} \\
& +\sum_{i=1}^{s} \beta_{1} \Delta Z-\text { score }_{t-i}+\sum_{i=0}^{r} \beta_{2} \Delta U N_{t-i}+\sum_{i=0}^{r} \beta_{3} \Delta X_{t-i}+\sum_{i=0}^{p} \beta_{4} \Delta H P I_{t-i} \\
& +\sum_{i=0}^{v} \beta_{5} \Delta H P I_{t-i}^{2}+\varepsilon_{t}
\end{aligned}
$$

In equation (4), the optimal lag will be chosen based on the lowest Akaike Information Criterion (AIC). $\alpha_{0}$ and $\varepsilon_{t}$ represent the intercept term and error term respectively, the long-run relationship between the stability and explanatory variable will be captured by the $\alpha_{1} \alpha_{2} \alpha_{3^{\prime}} \alpha_{4}$ and $\alpha_{5}$. Where the short-run relationship, are denoted by the term with summation sign. The p,q,r,s and $v$ are the lag length for the respective variable. As our study aims to identify the threshold level of 
house price in explaining the relationship, the turning point can be computed by$\left(\alpha_{4} / 2 \alpha_{5}\right)$. (. Indeed, the collateral hypothesis will be supported if the coefficient of $\alpha_{4}$ turn to be significantly positive in equation (4). However, coefficients of $\alpha_{5}$ will be negative and significant if the inverted U-shape relationship exists. In other words, the deviation hypothesis is supported- the bank is adversely affected given to the excessive run-up of house prices.

\section{RESULTS AND DISCUSSION}

\subsection{Results and Analysis}

Table 1.

Descriptive Analysis of the Variables

\begin{tabular}{lccccc}
\hline & Observations & Mean & $\begin{array}{c}\text { Standard } \\
\text { Deviation }\end{array}$ & Maximum & Minimum \\
\hline ZISL & 67 & 5.745 & 0.889 & 7.277 & 3.359 \\
HPI & 67 & 102.174 & 30.361 & 168.762 & 69.306 \\
UN & 67 & 3.339 & 0.288 & 4.076 & 2.799 \\
COST & 67 & 36.833 & 9.199 & 49.6 & 16.823 \\
\hline
\end{tabular}

We first presented the preliminary analysis of our data. In Table 1, the Z-score of Islamic banking is recorded highest at 7.28; and 3.36 at the lowest. On average, the Z-score reaches 5.75, and the series shows a marginal variation of 0.89 . As for house prices, the price index is reported relatively more variation, ranging from 69.31 to 168.76 point. Such a high variation could be explained by the rapid acceleration between the period 2010 to 2012, due to the government policy shift. The unemployment rate is rather steady and almost achieves full employment rate. The mean value of the unemployment rate reaches $3.34 \%$ and the highest at $4.08 \%$; lowest at $2.8 \%$. As far as the bank-specific variable is concerned, the dispersion for cost efficiency ratio (COST) reported approximate 9.2, with a minimum value of 16.82 and maximum at 49.6.

Prior to the estimation of the relationship, we determine the integration order of each series. We applied the commonly used stationarity test, Augmented Dickey-Fuller (ADF) and the Phillips Perron (PP) unit root test to determine the stationarity of the series.

Table 2.

ADF and PP Unit Root Test

\begin{tabular}{lcccc}
\hline \multirow{2}{*}{ Variable } & Level & \multicolumn{3}{c}{ First Difference } \\
\cline { 2 - 5 } & ADF & PP & ADF & PP \\
\hline ZISLt & $-2.84^{*}$ & -2.81 & $-6.55^{* * *}$ & $-6.58^{* * *}$ \\
HPIt & -1.41 & -0.05 & $-3.33^{*}$ & $-7.31^{* * *}$ \\
UNt & $-4.76^{* * *}$ & $-4.78^{* * *}$ & $-8.12^{* * *}$ & $-11.93^{* * *}$ \\
COSTt & -2.55 & -2.59 & $-6.20^{* * *}$ & $-10.43^{* * *}$ \\
\hline
\end{tabular}

Note: The constant and trend are included in the test equations. The SIC is used to select the optimal lag order in the ADF test equation. ${ }^{* * *}, * * *{ }^{*}$ denotes the significance at $1 \%, 5 \%$, and $10 \%$ respectively. 
Table 2 reports both the ADF and PP unit root tests; our result reveals that only unemployment is stationary at the level form. Meanwhile, z-score, house price index, and COST remained stationary after first difference by both test, suggesting property of I (1).

Our study employed the structural break unit root test (Z-A,1992) and Perron (1997) in order to capture a possible structural break. Our result of Z-A unit root tests and the break year for each of the variables are presented in Table 3. After addressing the breakpoint, the Zivot and Andrew unit root test suggest that all our series are stationary at the levels, except the cost to income ratio. The Perron unit root test draws a similar conclusion. Both tests conclude a quite consistent breakpoint. According to the test, the structural break is detected during the period of 2005 to 2010. As Z-score is the dependent variable, we will focus on the breakpoint of Z-score. Our test identified that the breakpoint for Z-score occurs in 2010Q3. Refer to Figure 1, Z-score shows a downward trend after 2010. The restructuring of the financial system may explain such a phenomenon. The number of Islamic banks increased to seventeen as banking licenses were issued to foreign Islamic banking players in 2010. This translated to greater competition among the Islamic banks and caused the unexpected shift in the series.

Table 3.

Zivot and Andrew (1992) and Perron (1997) Unit Root Test with Structural Breaks

\begin{tabular}{lcccc}
\hline \multirow{2}{*}{ Variables } & \multicolumn{3}{c}{ Zevel } \\
\cline { 2 - 5 } & t-statistics & Break year & t-statistics & Break year \\
& $-3.52^{* * *}$ & $2009 \mathrm{Q} 1$ & $-4.09^{* * *}$ & $2010 \mathrm{Q} 3$ \\
ZISL $_{t}$ & $-5.74^{* * *}$ & $2008 \mathrm{Q} 4$ & $-6.97^{* * *}$ & $2008 \mathrm{Q} 3$ \\
$\mathrm{HPI}_{\mathrm{t}}$ & $-5.30^{* * *}$ & $2010 \mathrm{Q} 2$ & $-5.24^{* * *}$ & $2010 \mathrm{Q} 1$ \\
$\mathrm{UN}_{\mathrm{t}}$ & $-4.59^{* * *}$ & $2007 \mathrm{Q} 3$ & $-6.24^{* * *}$ & $2007 \mathrm{Q} 2$ \\
COST $_{t}$ & & &
\end{tabular}

First Differences

$\begin{array}{lll}\Delta \text { ZISL }_{t} & -7.08^{* * *} & -7.08^{* * *} \\ \Delta \mathrm{HPI}_{t} & -4.02^{* * *} & -9.42^{* * *} \\ \Delta \mathrm{UN}_{t} & -8.56^{* * *} & -8.52^{* * *} \\ \Delta \text { COST }_{+} & -6.70^{* * *} & -6.83^{* * *}\end{array}$

Note: The constant and trend are included in the test equations. ${ }^{* * *}, * *, *$ denotes the significance at $1 \%, 5 \%$, and $10 \%$ respectively.

Since our stationarity test concluded that all of our series are integrated at both level and after difference, ARDL approach is the most appropriate method to estimate the long run and short run relationship. Below, we proceed to the bound test to identify the long-run cointegration. The ARDL bound test result is given in table 4: 
Table 4.

Critical Value Of The F-Statistic For The Bound Test Results with Unrestricted Intercept and No Time Trend

\begin{tabular}{lcccccc}
\hline $\mathbf{k}$ & \multicolumn{2}{c}{$\mathbf{9 9 \%}$ level } & \multicolumn{2}{c}{$\mathbf{9 5 \%}$ level } & \multicolumn{2}{c}{$\mathbf{9 0 \%}$ level } \\
\hline 4 & $\mathrm{I}(0)$ & $\mathrm{I}(1)$ & $\mathrm{I}(0)$ & $\mathrm{I}(1)$ & $\mathrm{I}(0)$ & $\mathrm{I}(1)$ \\
& 3.74 & 5.06 & 2.86 & 4.01 & 2.45 & 3.52 \\
F-statistic & & \multicolumn{3}{c}{7.97} \\
fZISL (HPI, HPI2, UN, COST) & \multicolumn{9}{c}{. } \\
\hline
\end{tabular}

Note: With a sample size of lesser than 100, the critical value is extracted from Narayan (2005), using an unrestricted intercept with no trend.

Table 5.

Effects of House Prices on Z-score for Islamic Bank. Model: ZISL=f(HPI, HPI2, UN, $(\mathrm{COST})^{2}$

\begin{tabular}{|c|c|c|}
\hline Dependent variable: ZISL & Coef & Std. Error \\
\hline \multicolumn{3}{|l|}{ Long-run Coefficients } \\
\hline Intercept & -0.4603 & 1.6629 \\
\hline $\mathrm{HPI}_{t}$ & $0.0724^{* *}$ & 0.0340 \\
\hline $\mathrm{HPI}_{2 \mathrm{t}}$ & $-0.0002^{*}$ & 0.0001 \\
\hline $\mathrm{UN}_{\mathrm{t}}$ & $-0.4007^{* * *}$ & 0.1356 \\
\hline COSTISL $_{t}$ & $-0.0346^{* *}$ & 0.0140 \\
\hline Error-correction coefficient & $-0.2233^{* * *}$ & 0.0634 \\
\hline \multicolumn{3}{|l|}{ Short-run Coeffcients } \\
\hline$\Delta \mathrm{HPI}_{\mathrm{t}-1}$ & -0.0495 & 0.0416 \\
\hline$\Delta \mathrm{HPI}_{\mathrm{t}-2}$ & 0.0623 & 0.1615 \\
\hline$\Delta \mathrm{HPI}_{\mathrm{t}-3}$ & $0.3308^{*}$ & 0.1647 \\
\hline$\Delta \mathrm{HPI}_{2 t}$ & 0.00003 & 0.0002 \\
\hline$\Delta \mathrm{HPI} 2_{\mathrm{t}-2}$ & -0.0006 & 0.0008 \\
\hline$\Delta \mathrm{HPI} 2_{\mathrm{t}-3}$ & $-0.0015^{*}$ & 0.0009 \\
\hline$\Delta$ COSISLT $_{t}$ & -0.0104 & 0.0118 \\
\hline$\Delta$ COSISLT $_{\mathrm{t}-1}$ & 0.0294 & 0.0118 \\
\hline$\Delta$ COSISLT $_{t-2}$ & 0.0151 & 0.0121 \\
\hline$\Delta \operatorname{COSISLT}_{\mathrm{t}-3}$ & $0.0246^{* *}$ & 0.0112 \\
\hline DUM & $-0.6262^{* * *}$ & 0.1711 \\
\hline $\mathrm{R}_{2}$ & 0.5583 & \\
\hline \multicolumn{3}{|l|}{ Diagnostic Test } \\
\hline Jarque Bera & 1.6642 & \\
\hline $\mathrm{LM}(2)$ & 4.1540 & $(0.1253)$ \\
\hline $\mathrm{ARCH}(2)$ & 1.3042 & $(0.5209)$ \\
\hline RESET(1) & 12.7807 & $(0.000)$ \\
\hline
\end{tabular}

2. Aforementioned, the Z-score series was interpolated. To ensure the robustness of estimation, $+/-5 \%$ of measurement error is added to the interpolated series, and value falls in the $+/-5 \%$ interval was randomly selected to form a new dataset. Then, the cointegration test is repeated. The F-statistic value is reported to be 7.04, in which indicating the present of cointegration relationship under the new dataset. Also, we repeated the estimation of equation (4) using the new dataset and found no significant difference in the sign of coefficient 
Table 4 indicates that the calculated F-statistic for our model is greater than the critical value of the upper bound 7.97 at $1 \%$ significance level. Thus, we have sufficient evidence to reject the null hypothesis of no cointegration between Islamic bank stability and the explanatory variables. Hence, we proceed with the estimation of the long run and short run relationship. The estimated long-run coefficients are presented in table 5 .

In Table $5^{3}$, our estimation suggests that the coefficient of the housing price, $\widehat{\alpha}_{4}$ is 0.0724 , and the quadratic term of the housing price, $\widehat{\alpha_{5}}$ is -0.0002 . This implicates that a 1-unit point increase in house price index results in approximately 0.324 unit $\left(\alpha_{4} / \alpha_{1}\right)$ increases in Z-score for an Islamic bank, assuming other variables are constant. On the one hand, the Z-score declines by $0.009\left(\alpha_{5} / \alpha_{1}\right)$ when the house price square rises by 10 -unit point. The long-run coefficients of unemployment rate appears to be significant. Z-score decreases by 1.79 unit $\left(\alpha_{2} / \alpha_{1}\right)$ for every 1 percentage point increase in the unemployment rate, when other variables are unchanged. Indeed, the negative relationship between the Z-score and the unemployment rate seems justified. Even though the Malaysian unemployment rate remains stable, it has a direct impact on the Z-score. The impact of a higher unemployment rate is transmitted to bank stability by lower demand for loans. Alleviation of the loan demand has significantly affected the bank's financial ratio, in particular, the ratio between an interest-bearing asset and a liability (Moinescu, 2012). Besides that, the cost to income ratio (COST) has been included as a bankspecific variable. The cost to income rate has been used as a proxy for management efficiency. Our result confirms that, in the long run, the Z-score rises by 0.155 unit for every unit point increase in the cost-to-income ratio, assuming other variables have not changed. Similarly, Koetter and Poghosyan (2010) argue that better cost efficiency enhances bank stability.

In the short run, our estimation provides evidence of the presence of nonlinearity relationship between housing prices and bank stability, but with a lagged. The Z-score seems to only respond to the house price changes after three quarters pass. Meanwhile, the short run coefficients for the cost to income ratio yield a positive sign implicates that higher cost to income ratio has a positive impact on the bank stability. One possible explanation is bank stability improved when the higher cost to income ratio generates more profit in the short run. As we found a structural break from 2010Q3, we have included a dummy variable to capture the effects of the restructuring of the financial system ${ }^{4}$. Our result indicates that the restructuring of the financial system in 2010 has a negative and significant effect on the Z-score. This implies the financial restructuring has eroded the Z-score of Islamic bank. Under a more competitive environment, the bank may strive to remain the profit margin and result in taking a riskier policy (Jimenez et al., 2013). To sum up, the outcome is supportive of the deviation hypothesis, in which consistent with the study by Von Peter (2009) and Gerlach \& Peng (2005).

\footnotetext{
3. ROA, ROE and Cost to income ratio are the control variables. However, only cost to income ratio is found to be significantly related to the Z-score. As such, our result in table 5 has not included ROA and ROE. The optimal lag length was selected according to the AIC, lag order 4 was selected by the criterion. General to specific approach is adopted and obtain the final specification in table 4.

4. In 2010, Malaysian government has issued more new banking license to the foreign bank. The banking industry may become more competitive.
} 
Importantly, the relationship is suggested to be concave as opposed to the linear relationship found in the past studies. Such finding provides implications that a persistent expansion of house prices in Malaysia increases the exposure of bank after a certain threshold value.

The residual diagnostic tests of normality, heteroscedasticity, and autocorrelation are performed to ensure the model is adequately estimated. Results are presented in table 4 . All tests are reported to be insignificant and indicating the estimations meets with the underlying classical assumption. The stability test of recursive residuals using CUSUM and CUSUM square in appendix B (figure 2 \& 3 ) ascertain that the estimated parameters are stable at $5 \%$ level and no evidence showing that the model is mis-specified.

Figure 2.

CUSUM (ZISL=f(HPI, HPI2, UN, COST).

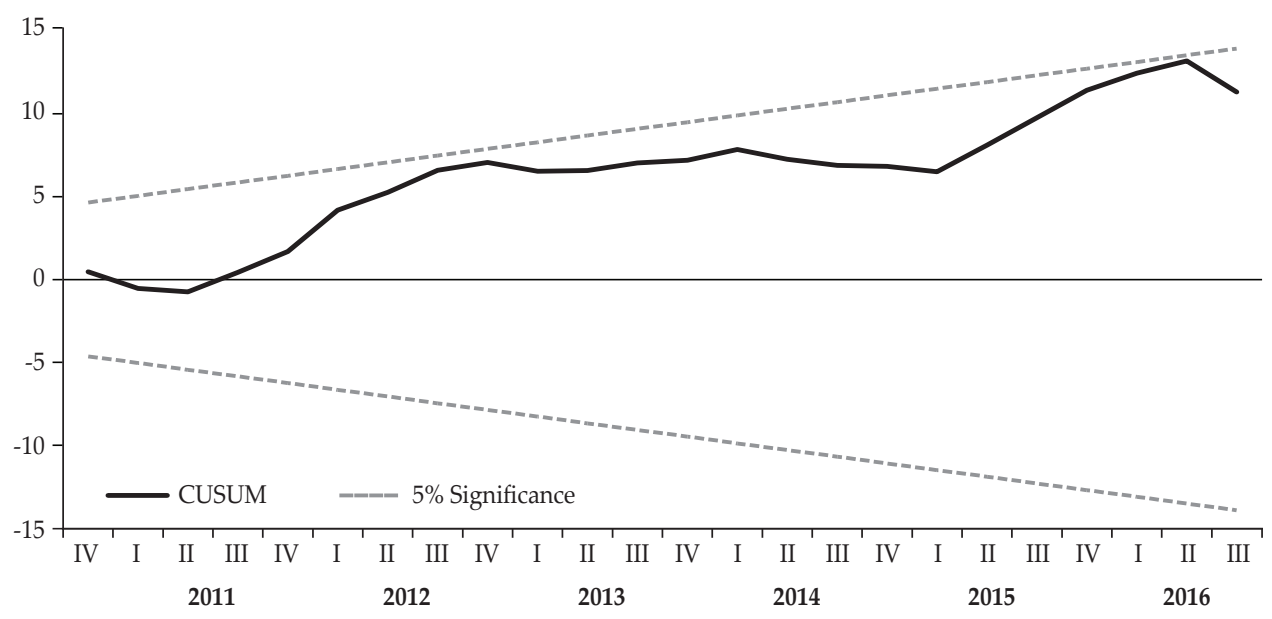

Figure 3.

CUSUMSQ (ZISL=f(HPI, HPI2, UN, COST)

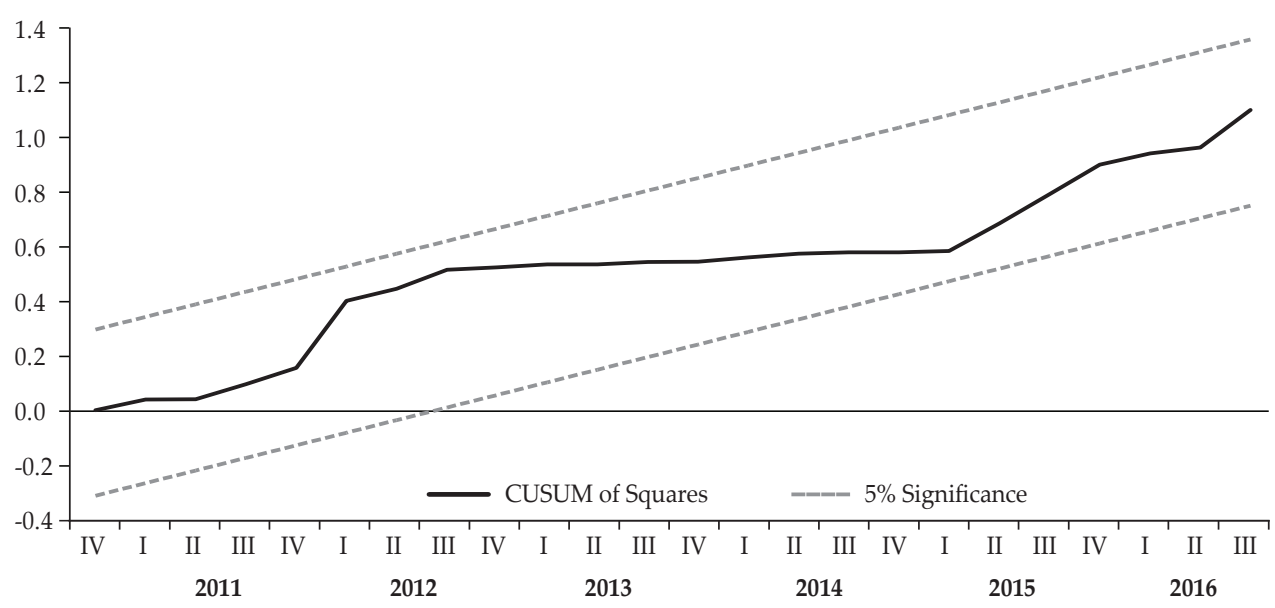




\subsection{Proper test for U-shaped or inverted U-shape}

As the conventional econometric model is inadequate in testing the null hypothesis of the existence of a quadratic relationship between the variables (Lind and Mehlum, 2010), U-test is applied to confirm our findings of the non-monotonic relationship between the bank stability and house prices. The result is presented in table 6.

Table 6.

Test of A U-Shape and Inverted U-Shaped Relationship.

\begin{tabular}{lc}
\hline & ZISL \\
\hline Slope at HPImin & $0.0367^{*}$ \\
Slope at HPI max & -1.5555 \\
& $-0.0334^{* * *}$ \\
Sasabuchi-Lind-Mehlum (SLM) test of U-Shape or & $(-2.4007)$ \\
inverted U-Shape & 1.56 \\
& \\
P-value & 0.0625 \\
Estimated extreme threshold Point & 121.398 \\
99\% confidence of Fieller interval & {$[69.306,168.762]$} \\
\hline
\end{tabular}

Notes: T-value in parenthesis. ${ }^{* * *}$ and ${ }^{*}$ indicates significant at $1 \%$ and $10 \%$ level.

If the null hypothesis is rejected, the non-monotonic relationship between variables can be confirmed. Our result reveals that the lower bound slope of house price index is positive (0.0367) and negative in the upper bound slope (-0.033). Both lower and upper bound slopes are statistically significant. This reflects that the hypothesis of no U-shape relationship between house price and Z-score is rejected. In other words, our model suggests that an inverted U-shape relationship exists between house price and Z-score. In sum, the result of Sasabuchi-Lind-Mehlum (SLM) test validates our findings present in table 5.

\section{CONCLUSION AND RECOMMENDATION}

\subsection{Conclusion}

The Islamic banking industry has a long history in Malaysia. Within three decades this industry has accumulated USD65.5 billion and with a stable annual growth rate of $18-20 \%$. Recognizing the great role of Islamic banking in Malaysia, we evaluated the impact of house price on Islamic bank stability. In looking at a relationship between house price and bank stability, we considered the nonlinear perspective. Our study employed the ARDL model, introduced the quadratic polynomials of house price in the estimation. The result we obtained suggests a nonlinear relationship between house price and Z-score. More importantly, the relationship should be indeed a concave relationship, which hints the "fundamental-deviation effect" that dominated the "collateral value effect" when the price further expanded. The persistent deviation from the fundamental result in the buildup of risk. The finding is confirmed by conducting the U-test, which revealed that Z-score started to drop when house price exceeded 121.398. 


\subsection{Recommendation}

To sum up, the finding is particularly significant for both researchers and industry practitioners to have a better position to carry off the potential financial risk well with proper practice. For the policymakers, this study provides implication and raises concern over the upsurge of the property price in the most recent year. As our study found evidence of a concave relationship between house price and Z-score, this suggests that the stability depends upon the low or high level of the house prices. When the house price is high and is deviated from the fundamental, the bank risk increases, even though by law, an Islamic bank is not permitted to hold any risky asset, the persistent raised of housing prices may cause an imbalance in the housing market and jeopardize the bank stability. To ensure the soundness of the bank, policymakers should focus on maintaining the optimal growth of house price. In doing so, our study suggests the policy may direct to limit the homeownership or individual purchase limit, especially the foreigner. This could help to curb the excessive growth of house price. Meanwhile, based on our finding, efficiency in cost management is also vital to reduce the risk of an Islamic bank. The cost efficiency of a bank was generally considered as a central focus to remain the bank's competitiveness. The more cost efficiency the bank, the better bank's performance and stability.

\section{REFERENCES}

Abdul-Rahman, A. (2009). Lending Structure and Market Risk Exposures: The Malaysian Case. Asian Academy of Management Journal, 14(2), 1-20.

Abdul-rahman, A., Mohd Said, N. L. H., \& Sulaiman, A. A. (2017). Financing Structure and Liquidity Risk: Lesson from Malaysian. Journal of Central Banking Theory, 2, 125-148. http://doi.org/10.1515/jcbtp-2017-0016

Abedifar,P., Molyneux,P., \& Tarazi, A. (2013). Risk in Islamic Banking. Review of Finance, 17(6), 2035-2096.

Ahmed, H., Asutay, M., \& Rodney, W. (2014). Reflecting on Islamic Banking and Financial Crisis: Reputation, Stability and Risk. In H. Ahmed, M. Asutay, \& R. Wilson (Eds.), Islamic Banking and Financial Crisis: Reputation, Stability and Risk (pp. 1-20).

Allen, F., \& Gale, D. (2001). Comparing Financial Systems. Cambridge, MA:MIT Press.

Alqahtani,F., \& Mayes,D.G.(2018). Financial Stability of Islamic Banking and The Global Financial Crisis: Evidence From The Gulf Cooperation Council. Economic Systems, 42, 346-360.

Baele, L., Farooq, M., \& Ongena, S. (2014). Of Religion and Redemption : Evidence From Default on Islamic Loans. Journal of Banking and Finance, 44, 141-159. http://doi.org/10.1016/j.jbankfin.2014.03.005

Beck, T., Jonghe, O. De, \& Schepens, G. (2013). Bank Competition and Stability : Cross-country Heterogeneity. Journal of Financial Intermediation, 22(2), 218-244. http://doi.org/10.1016/j.jfi.2012.07.001

Bernanke, B., \& Gertler, M. (1989). Agency Costs, Net Worth, and Business Fluctuations. The Americal Economic Review, 79(1), 14-31. 
BNM. (2018). Bank Negara Malaysia Monthly Highlights and Statistics in December 2018. Retrieved from http://www.bnm.gov.my/index.php?ch=en_ publication\&pg=en_msb\&ac=265\&lang=en\&uc=2

Bongini, P., Claessens, S., \& Ferri, G. (2001). The Political Economy and Distress in East Asian Financial Institutions. Journal of Financial Services Research, 19(1), 5-25.

Bourkhis,K., \& Nabi, M.S. (2013). Islamic and Conventional Bank's Soundness during the 2007-2008 Financial Crisis. Review Financial Economics, 22(2), 68-77.

Boyd, J. H. \& De Nicolo, G. (2005). The Theory of Bank Risk Taking and Competition Revisited. The Journal of Finance, 60(3), 1329-1343.

Calomiris, C. W., \& Mason, J. R. (2003). Fundamentals, Panics, and Bank Distress during the Depression. American Economic Review, 93(5), 1615-1647.

Cebula, R., Koch, J., \& Fenili, R. (2011). The Bank Failure Rate, Economic Conditions and Banking Statutes in the U.S., 1970-2009. Atlantic Economic Journal, 39(1), 39-46.

Chakroun, M. A., \& Gallali, M. I. (2011). Risk and Stability in Islamic Banking. International Journal of Business and Commerce, 5(3), 64-87.

Chen, N-K. (2001). Bank Net Worth, Asset Prices and Economic Activity. Journal of Monetary Economics, 48, 415-436.

Chiesa, G. (2001). Incentive-based Lending Capacity, Competition, and Regulation in Banking. Journal of Financial Intermediation, 10, 28-53.

Choong, Y.V., Thim,C.K., \& Kyzy, B.T. (2012). Performance of Islamic Commercial Banks in Malaysia: An empirical study. Journal of Islamic Economics Banking and Finance, 8, 67-79.

Cihak,M., \& Hesse,H. (2010). Islamic Bank and Financial Stability: An-Empirical Analysis. Journal of Financial Services Research, 38(2-3), 95-113.

DeYoung,R., \& Torna,G. (2013). Nontraditional Banking Activities and Bank Failures during The Financial Crisis. Journal of Financial Intermediation, 22(3), 397-421.

Diamond, D.W.,\& Rajan, R.G.(2006). Money in a Theory of Banking. The American Economic Review, 96(1), 30-53.

Dieci, R., \& Westerhoff, F. (2012). A Simpe Model of a Speculative Housing Market. Journal of Evolutionary Economics, 22(2), 303-329. http://doi.org/10.1007/s00191011-0259-8

Gennaioli, N., Shleifer, A., \& Vishny, R. (2012). Neglected Risks, Financial Innovation, and Financial Fragility. Journal of Financial Economics, 104(3), 452468. http://doi.org/10.1016/j.jfineco.2011.05.005

Gerlach,S., \& Peng,W. (2005). Bank Lending and Property Prices in Hong Kong. Journal of Banking and Finance, 29, 461-481.

Gersbach, H. (2002). Financial Intermediation and The Creation of Macroeconomics Risks. Cesifo Working Paper No.695(6), April 2002.

Hasan, M., \& Dridi, J. (2010). The Effects of the Global Crisis on Islamic and Conventional Banks : A Comparative Study (IMF Working Paper No. WP/10/201).

Holmstrom,B., \& Tirole,J. (1997). Intermediation, Loanable Funds, and Real Sector. The Quarterly Journal of Economics, 112(3), 663-691.

Jiménez, G., Lopez,J.A., \& Saurina, J.(2013). How Does Competition Affect Bank Risk-Taking? Journal of Financial Stability, 9(2), 185-195. 
Keeley, M.C. (1990). Deposit Insurance, Risk and Market Power in Banking. American Economic Review, 80, 1183-1200.

Khaddafi, M., Falahuddin, Heikal,M., \& Nandari, A. (2017). Analysis Z-Score to Predict Bankcrupty in Banks Listed in Indonesia Stock Exchange. International Journal of Economics and Financial Issues, 7(3), 326-330.

Khor,H.E., \& Kee, R.X. (2008). Asia: A Perspective on the Sub-Prime Crisis. Finance \& Development, 45(2), accessed 10 June 2017 at https://www.imf.org/external/ pubs/ft/fandd/2008/06/khor.htm

Kiyotaki, N., \& Moore, J. (1997). Credit Cycles. Journal of Political Economy, 105(2), 211-247.

Koetter, M., \& Poghosyan, T. (2010). Real Estate Prices and Bank Stability. Journal of Banking and Finance, 34(6), 1129-1138. http://doi.org/10.1016/j. jbankfin.2009.11.010

Kosmidou,K., Tanna, S., \& Pasioures, F. (2005). Determinants of Probability of Domestic UK Commercial Bank: Panel Evidence From 1995-2002, Money Macro and Finance MMF Research Group Conference.

Li, Y.J.(2015). Geography of Crime in China since The Economic Reform of 1978: A Multi Scale Analysis.UK: Cambridge Scholar Publishing.

Lind, J. T., \& Mehlum, H. (2010). With or Without U? The Appropriate Test for a U-Shaped Relationship. Oxford Bulletin Economics Statistics, 72(1), 109-118.

Messai A, S., \& Gallali, M. (2015). Financial Leading Indicators of Banking Distress: A Micro Prudential Approach - Evidence from Europe. Asian Social Science, 11(21), 78-90.

Moinescu, B-G. (2012). Determinants of Nonperforming Loans in Central and European Countries: Macroeconomics Indicators and Credit Discipline. Review of Economic and Business Studies, 5(2), 47-58.

Pan, H., \& Wang, C. (2013). House Prices, Bank Instability, and Economic Growth: Evidence from the Threshold Model. Journal of Banking and Finance, 37(5), 1720-1732. http://doi.org/10.1016/j.jbankfin.2013.01.018

Reinhart, K. S., \& Rogoff, K.S. (2008). This Time Is Different: A Panoramic View of Eight Centuries of Financial Crises (NBER Working Paper No. 13882). Retrieved from National Bureau of Economic Research website: http://www.nber.org/ papers/w13882

Von Peter, G. (2009). Asset Prices and Banking Distress: A Macroeconomics Approach. Journal of Financial Stability, 5, 298-319. http://doi.org/10.1016/j. jfs.2009.01.001

Vogiazas, S. D., \& Nikolaidou, E. (2011). Investigating the Determinants of Nonperforming Loans in the Romanian Banking System: An Empirical Study with Reference to the Greek Crisis. Economics Research International, 1-13.

Wasiuzzaman, S., \& Tarmizi, H.A.B.A.(2010). Profitability of Islamic banks in Malaysia: An Empirical Analysis. Journal of Islamic Economic Banking and Finance, 6, 53-68.

Zarrouk, H. (2012). Does Financial Crisis Reduce Islamic Bank's Performance? Evidence form GCC Countries. Journal of Islamic Finance and Business Research, 1, 1-16. 


\section{Appendix.}

Table A1.

Sample of Banks

\begin{tabular}{clc}
\hline No. & Local Banks & Sample Period \\
\hline 1 & Maybank Islamic Berhad & $2000-2016$ \\
2 & Public Islamic Bank Berhad & $2000-2016$ \\
3 & CIMB Islamic Bank Berhad & $2000-2016$ \\
4 & Hong Leong Islamic Bank Berhad & $2000-2016$ \\
5 & RHB Islamic Bank Berhad & $2000-2016$ \\
6 & Ambank Islamic Berhad & $2000-2016$ \\
7 & Affin Islamic Bank Berhad & $2000-2016$ \\
8 & Alliance Islamic Bank Berhad & $2001-2016$ \\
9 & Bank Muamalat Malaysia Berhad & $2001-2016$ \\
\hline
\end{tabular}


This page is intentionally left blank 